\title{
Empirikus kutatások és gyakorlati tapasztalatok a konszekutív jegyzeteléstechnikában
}

\author{
Szabó Csilla \\ E-mail:szcsilla@inyk.bme.hu
}

\begin{abstract}
Kivonat: A konszekutív, hosszúszakaszos tolmácsolás során alkalmazott jegyzeteléstechnika oktatása szinte minden képzőintézményben szerepel a tantervben, de az alapelveket illetően jellemzően ritka a konszenzus. A tanulmány a jegyzeteléstechnika oktatásában felmerülő három legfajsúlyosabb dilemmát járja körül: (1) Mit/Mennyit írjunk le: kulcsszavakat, föbb adatokat, vagy amit csak lehet? (2) Hogyan jegyzeteljünk: egész szavakat, rövidítéseket vagy szimbólumokat érdemesebb papírra vetni? (3) Milyen nyelven: forrásnyelven vagy célnyelven, A illetve B nyelven, vagy - a nyelvi irány tól függetlenül - a leggazdaságosabbnak ítélt nyelven, pl. angolul? Mindhárom kérdéskör vonatkozásában elsőként megvizsgájuk, hogy milyen preskriptív jellegü tanácsok, illetve módszertani javaslatok születtek az elmúlt néhány évtizedben e problémák feloldására, illetve kezelésére. A következő lépésben számba vesszük az adott kérdéssel foglalkozó fontosabb empirikus kutatásokat, majd végül levonunk néhány lehetséges módszertani tanulságot, amelyet a szerző személyes oktatói tapasztalata alapján fogalmaz meg.
\end{abstract}

Kulcsszavak: empirikus kutatások, jegyzeteléstechnika, nyelvspecifikus vs. nyelvfüggetlen jegyzetelés, konszekutív tolmácsolási kapacitások.

\section{Bevezetés}

A konszekutív (követő) tolmácsolás a konferenciatolmácsolás olyan válfaja, amikor a tolmács a beszélö által elöadott szöveget hosszabb vagy rövidebb (néhány másodpercig tartó egységtől egész 6-7 percig terjedö), összefüggő szakaszokban közvetíti a hallgatóságnak. Noha a klasszikus (min. 5 perces) és a rövidszakaszos tolmácsolás között nehéz különbséget tenni (González et al., 1991/2012), hagyományosan inkább a hosszú szakaszos változatot szoktuk konszekutív tolmácsolásnak hívni (Jones 1998 illetve Láng 2002), és igazából itt van szükség jegyzetelésre is.

Hivatkozás: Szabó Cs. 2020. Empirikus kutatások és gyakorlati tapasztalatok a konszekutív jegyzeteléstechnikában. Fordítástudomány 22 évf. 1. szám. 86-104.

DOI: https://doi.org/10.35924/fordtud.22.1.6 
A jegyzetelés a követő tolmácsolás fontos, integráns része, melynek során a tolmács a beszéd struktúráját és logikáját papíron rögzíti. Ennek célja nem a bejövő információ minél pontosabb lejegyzetelése, hanem a tolmács memóriájának támogatása. ${ }^{1}$ Manapság egyre ritkábban van igény a piacon hosszú szakaszos konszekutív tolmácsolásra, a képzőintézmények képesítő vizsgáin azonban ragaszkodnak ehhez, hiszen egy 6-8 perces konszekutív beszéd kifejezetten alkalmas lehet arra, hogy megmutatkozzon egy jelölt pályaalkalmassága. A jelöltek sokszor már a szóbeli vizsgán is kapnak ilyen jellegű feladatot, az év végi záróvizsgán pedig nemcsak anyanyelvükre (A nyelv), de az erösebb idegen nyelvükre (B nyelv) is tudniuk kell (jegyzeteléssel) tolmácsolni egy általános jellegủ vagy akár egy némileg specifikusabb témában előadott beszédet.

A jegyzeteléstechnika tehát egy olyan, kimondottan jelentős eleme a konszekutív tolmácsolás oktatásának, amelyre minden tolmácsképző intézmény figyelmet fordít, ugyanakkor az alapkérdésekben - Mit/Mennyit?, Hogyan?, Milyen nyelven? - több évtized elteltével sem alakult ki konszenzus. Az alábbiakban ezt a három visszatérő dilemmát fogjuk megvizsgálni úgy, hogy először (a teljesség igénye nélkül) áttekintjük a leíró jellegü, bizonyos ajánlásokat megfogalmazó korábbi munkákat, majd megnézünk néhány, a témához releváns empirikus kutatást azzal a céllal, hogy ezek alapján megfogalmazzunk néhány lehetséges módszertani javaslatot.

\section{Jegyzeteléstechnika: Mit írjunk le? Mennyit jegyzeteljünk?}

\subsection{Mit és mennyit: preskriptív jellegü munkák}

Amennyiben rövid áttekintést szeretnénk nyújtani a jegyzeteléstechnika oktatásában a Mit/Mennyit? kérdésben született preskriptív jellegü írásokról, nehéz a dolgunk, hiszen a Hogyan? kérdése alapvetően összefonódik a fent feltett kérdésekkel. Ha visszatekintünk a kezdetekre, azt láthatjuk, hogy a konszekutív tolmácsok az ősidőkben ugyan legendás módon alkalmazták a követő móduszt, ám többségük, ha jegyzetelt egyáltalán, jellemzően nem használta a leírtakat - pl. maga Rozan sem (Ilg és Lambert 1996: 71). Jean Herbert ENSZ-tolmács (1952) volt az első, aki a jegyzetelés szerepéről és folyamatáról írt; aki a parafrazálás fontosságát hangsúlyozta, és minimális jegyzeteket javasolt (Ilg és Lambert 1996:71), de ennél pontosabban nem foglalkozott a kérdéssel.

A legfontosabb alapelv a Mit? kérdés megfogalmazásával kapcsolatban a többség részéről az volt, hogy ne szavakat, hanem gondolatokat jegyzeteljünk. E tétel első megjelenése a párizsi ESIT (École Supérieure d'Interprètes et de Traducteurs) vezetője, Danica Seleskovitch nevéhez köthető, aki kolléganőjével, Marianna Ledererrel közösen dolgozta ki az ún. interpretatív modellt, amelynek középpontjában a derverbalizációs elv áll. Ennek lényege, hogy a tolmács nem szavakat jegyez meg (és jegyzetel), hanem a szószinttől és a szavak formájától elvonatkoztatva 
mintegy „gondolkodva”, a jelentést (sens) értelmezve tolmácsol (Seleskovitch és Lederer 1995; Láng 2002: 75). Ez az alapelv több későbbi munkában is visszaköszön, noha eltérő szóhasználatban: egyesek szerint az üzenet megértése meg kell, hogy előzze a jegyzetelést (pl. Deng 1991: 285), mások az elemzést látják a jegyzetelés előfeltételének (pl. Alexieva 1994: 206; Chuang 2008: 95); Gillies szerint pedig a lényeg a gondolat megragadása (Gillies 2004: 53).

A jegyezeteléstechnika oktatására vonatkozó első átfogó mü Jean-François Rozan tollából született 1956-ban, amely a mai napig a föbb tolmácsképzők kötelezőolvasmány-listáján szerepel. Köszönhető ez annak is, hogy a jegyzeteléstechnikai minimum és maximum között terjedő relatíve széles skálán ő képviseli az arany középutat. Rozan nyelvészeti, szemantikai és kognitív szempontból is elemzi a bejövő forrásszöveget, és elsőként emeli ki a jelentés fontosságát (noting the idea, not the word). Rozan hét alapelve között (1956/2004: 15) a Mit, mennyit és hogyan? kérdésekre vonatkozó javaslatok vegyesen szerepelnek (rövidítések, logikai összekötő elemek, tagadás jelzése, hangsúlyok, függőleges irány, lépcsőzetes eltolás).

Heinz Matyssek 1989-es komplex szimbólumrendszeréről részletesebben majd a jegyzetek formájára vonatkozó preskriptív munkák kapcsán szólunk, de a Mit és mennyit? kérdés vonatkozásában Matyssek is egyetért a fent idézett szerzőkkel, és a jelentés megragadását (tragenden Essenz) jelöli meg, mint legfontosabb szempont. Roderick Jones 1998-as összefoglaló müvében ugyanezt a fontos alapelvet fogalmazza meg, és hozzáteszi, hogy az üzenetet alkotó főbb gondolatok lejegyzetelése azért is kulcsfontosságú, mert ezek alkotják a beszéd vázát (1998: 41). Jones alapvetően Rozan elveivel ért egyet, ugyanakkor olyan elemeket is lejegyzésre érdemesnek talál, mint az igeidők vagy a beszélő véleménye. Roderick Jones (illetve ezt alapul véve később Andrew Gillies) válasza a Mit? kérdésre nyelvészeti alapon nyugszik: javaslata(ik) alapján minden beszéd lebontható és lejegyzetelhető az SVO-struktúra alapján (azaz: alany-állítmány-tárgy: ki mit csinál kivel/mivel), mégpedig az adott nyelvtani struktúrától és szórendtől függetlenül. Hangsúlyozzák azonban, hogy a konszekutív tolmácsolás lényege az, hogy a számos beérkező információból kihámozzuk a fö üzenetet (Gillies 2017: 36), és a jegyezetek segítsék az információ előhívását (Jones 2014: 41).

Nyilvánvalónak tünhet Rozan, Jones vagy Gillies tanácsa, hogy a fö információhordozó elemeket, azaz a kulcsszavakat érdemes leírni, ugyanakkor több tapasztalt tolmács is azon a véleményen van, hogy csak azt érdemes lejegyezni, amit amúgy a memóriánk nehezen tárolna. Az, hogy mit és mennyit írunk le, nagyban függ a beszéd témájától is: ha a tolmács jártas az adott területen, ismeri a neveket, fogalmakat és összefüggéseket, sokkal kevésbé kell tehermentesítenie a memóriáját, hiszen a fontos adatokat nem a rövid, hanem a hosszú távú memóriából kell előhívnia. Egyértelmü jelentősége van tehát a szakmai (szakterületi) ismereteknek, illetve az alapos felkészülésnek egy-egy konszekutív megbízás esetén, s a képzőintézményeknek legalább akkora hangsúlyt kell helyezniük a tolmácseseményekre történő felkészülésre, mint a tolmácsolási technikák elsajátítására. 


\subsection{A jegyzetek tartalma - mit és mennyit: empirikus kutatások}

A Mit/mennyit? kérdésre vonatkozó empirikus kutatások viszonylag szórványosak. Említést érdemel Gile 1991-es vizsgálata (idézi Chen 2016: 157), amely minden bizonnyal hozzájárult a szerző későbbi, a tolmácsolási kapacitásokkal kapcsolatos elméletének kialakításához (Gile 1995/2009). Ebben a kutatásban az egyik kísérleti csoport jegyzetelhetett, míg a másiknak csak az elhangzott neveket volt szabad leírnia. Az eredmények azt mutatták, hogy az első csoport tagjai pontatlanabbul írták le a neveket, hiszen a szöveg egészére koncentráltak, és a jegyzetelés elvonta a figyelmüket. Több kísérlet is kimutatta, hogy a tolmácsok hajlamosak túl sokat jegyzetelni (Thiéry 1981; Seleskovitch 1975/2002; Mead 2011). Érdekes vizsgálatokról olvashatunk a szinkrontolmácsolás kutatásából átvett ear-voice-span (követési távolság, azaz mennyi idő telik el a fülön keresztül beérkező és a szájon keresztül távozó információ között) analógiájára kialakított ear-pen-span témájában (azaz mennyi idő telik a bejövő információ és a papírra vetés között - Chen 2017a és 2017b). Egy egészen friss, 2018-as kutatás (Yamada 2018) pedig azt erösítette meg, hogy a jegyzetelés nem feltétlenül vezet jobb tolmácsoláshoz. Ebben a tekintetben korábban is sok volt a szkeptikus hang, és föleg a francia iskola képviselői (pl. Thiéry) nem látták értelmét a jegyzetelés oktatásának (Chen 2016: 156; Ilg és Lambert 1996: 78). A fentiek alapján látható tehát, hogy az empirikus módon szerzett adatok alapján nehéz meghatározni, hogy mit, illetve mennyit érdemes jegyzetelni. A kérdést - valamint a kutatások validitását - tovább bonyolítja, hogy a jegyzeteket a produkció (kimenet) minőségének függvényében lenne igazán érdemes vizsgálni; a minőség fogalma a tolmácsolásban (illetve a fordítástudomány minden területén) rendkívül összetett kérdés. ${ }^{2}$

\subsection{A jegyzetek tartalma - mit és mennyit: javaslatok oktatóknak}

A legtöbb gyakorló tolmács szerint a konszekutív tolmácsolás kezdeti szakaszában nem szabad egyből „nekiesni” a jegyzetelésnek (Seleskovitch 1999: 64); elöször az ún. gist-recall feladatokat (,memókat”), tehát a jegyzetek nélküli információ-elöhívási feladatokat érdemes gyakorolni (Láng 2002: 143), hiszen a hallgatóknak meg kell érteni (érezni) a tolmácsolás folyamatát. Erre a szakaszra nézve többféle iskola is létezik: egyesek szerint érdemes olyan beszédeket választani, amelyekben sok a panel és az anticipálható fordulat (pl. megnyitó beszédek); az ilyen szövegekkel szintén jól lehet gyakorolni a megszólításokat, neveket, számokat, földrajzi kifejezéseket is Mások szerint éppen olyan szövegeket érdemes az első szakaszban adni, amelyben kevés a jegyzeteléssel jól rögzíthetö elem, érdemes viszont szinte eröltetetten hangsúlyozni a logikai viszonyokat (ok-okozat, tézis-antitézis, stb.), hogy a hallgatók a beszédek felépítését lássák át mihamarább.

Azt, hogy magát a jegyzetelést mikor vezetjük be, és milyen sorrendben tanítjuk, egyéni oktatói ízlés dolga. Arra azonban mindenképpen hívjuk fel a hallgatók figyelmét, hogy a jegyzetelés kezdeti, kísérleti fázisában romlani fog a tolmácso- 
lási teljesítményük (ezt longitudinális kutatások is megerősítették (pl. Alexieva 1994: 200), és hogy ez egy természetes folyamat, amely türelmet igényel. Ebben az időszakban egyetlen dologra érdemes koncentrálni: legyen meg a beszéd váza; nem baj, hogyha apró pontatlanságok vannak, vagy hiányzik pár adat. Egy másik közhely, amire a hallgatók figyelmét már a kezdeti fázisban felhívjuk az az, hogy legyen meg pontosan a beszéd eleje és vége: a jó kezdés és a frappáns befejezés már fél siker.

Szintén egyértelmü, hogy az adatokat mindenképpen érdemes papírra vetni; a nevek, számok, hosszas listák ne terheljék feleslegesen a memóriát. A számokat például nem tudjuk utólag kihámozni a kontextusból, ezért ezek megtartása nagyobb terhet ró a memóriára, következésképpen érdemes ezeket azonnal elhangzáskor leírni, és ezt követően visszakanyarodni a gondolatmenethez (Dingerfelder 2014: 162) .

Nem árt az oktatónak a tolmácsolandó beszédeket a komplexitás függvényében megválasztani. A komplexebb beszédek kiválasztásánál át kell gondolni a beszéd ,szintjét”: a Speech Repository-ban szintek szerint lehet keresni (kezdő, közepesen nehéz, haladó, vizsgaszint), és érdemes átolvasni a Setton és Dawrantkötet (2016b) idevonatkozó részét is, amely a beszéd nehézségét osztályozó indexről szól (Speech Difficulty Index, SDI, illetve ld. még Besznyák elökészületben).

Szintén fontos, hogy a konszekutív stúdiumokon minden órán legyen olyan (gist-recall/memó) feladat, ahol a hallgatók nem jegyzetelhetnek, vagy csak „kulcsszavazhatnak”. Érdemes házi feladatként feladni, hogy ugyanazt a szöveget először próbálják ki kulcsszavakkal, SVO-módszerrel (Gillies 2017), illetve teljes jegyzeteléssel - tapasztalataikat pedig írják le a tolmácsolási naplóba (lásd logbook). ${ }^{3}$ Setton és Dawrant felhívja a figyelmet arra is, hogy ha a hallgatóknak hosszabb ideig kell jegyzetelniük (akár egy mock konferencián), látni fogják, hogy egyre kevesebbet írnak le - már csak a fáradtság okán is (2016b: 193). Érdemes ráébreszteni őket, hogy a kevesebb jegyzet is kellően hatékony lehet, és ily módon is felhívni a figyelmüket, hogy a kevesebb néha több.

\section{A jegyzetek formája: hogyan jegyzeteljünk?}

A jegyzeteléstechnika kutatásának és oktatásának másik legfontosabb területe a jegyzetek formai megjelenítéséhez kapcsolható. Jegyzeteléskor a tolmács több lehetőségből választhat: leírhat teljes szavakat, rövidíthet és egyszerüsíthet, használhat szimbólumokat, illetve vizuális megjelenítésre alkalmas egyéb kódot (pl. rajzot). 


\subsection{A jegyzetek formája: preskriptív munkák}

\subsubsection{Szimbólumok}

Rozan szerint nem érdemes túl sok szimbólumot használni, mert a szimbólum előhívása önmagában is sok energiát emészthet fel, amely elvonhatja a figyelmünket az üzenet értelmezésétől (1956/2004: 25), ezért minimalizálja a használandó szimbólumokat, és kisebb csoportra osztva javasolja azok alkalmazását. Három fö csoportot jelöl meg: a) kifejezésmódokra alkalmazott szimbólumok (pl. mondja, gondolja, tárgyalja stb.); b) mozgás kifejezésére szolgáló szimbólumok (pl. növekvő, csökkenő tendenciák stb.), illetve $c$ ) megfeleltetések, viszonyok kifejezésére alkalmazott jelek (pl. reláció, egyenlőség, összehasonlítás stb.).

A fentiek mellett a gyakorta előforduló fönevek/melléknevek kifejezésére is megad bizonyos jeleket (pl. ország, nemzetközi, globális, munka, kereskedelem stb.), ezek kiválóan kombinálhatók egymással.

A jegyzeteléstechnika elsősorban formai mikéntjét vázolni kívánó művek egyik végletes példája a heidelbergi iskola jeles képviselöje, Heinz Matyssek 1989-es opusza. Matyssek olyan komplex szimbólumrendszert dolgozott ki, amellyel praktikusan minden nyelvi elem kifejezhető, és az egyes szimbólumok megfelelö kombinációjával minden pontosan lejegyezhető. Ugyan a szimbólumok száma elképesztően magas, mindazonáltal Matyssek rendszere az alapvetések terén nagyon sok közös vonást mutat elödei (pl. Herbert vagy Rozan) alapelveivel (Sawyer 2004: 24, Ahrens 2005, illetve Setton és Dawrant 2016b: 203). Matyssek rendszerének további pozitív vonása, hogy nyelvfüggetlen jegyzetelést tesz lehetővé. Ennek ellenére a módszer számos kritikát kapott (pl. hogy szimbólumrendszere annak túlzottan aprólékos volta miatt olyan, mint egy új gyorsírási szisztéma), ám a német iskola bebizonyította, hogy ez a szélsőséges módszer is müködőképes lehet, hiszen tolmácsgenerációk egész sora sajátította el és alkalmazta hatékonyan, ráadásul alapul szolgált további jegyzeteléstechnikai rendszerek számára. E szimbólumrendszert továbbfejlesztve alakította ki például Allioni (1989) a maga nyelvspecifikus jegyzeteléstechnikáját, amely szintén külön kódrendszer révén, egyfajta metanyelvi alapon müködik. Érdemes további tanulmányokat is felidézni ebből az időszakból: feltétlen ide tartozik Becker müve (1972), amelyet a germesheimi iskola oktatásában használtak, és valahol Rozan és Matyssek közé tehető - legalábbis a javasolt szimbólumok számának tekintetében. Érdekes továbbá a már korábban említett Thiéry könyve is (1981), amely egyáltalán nem javasolja a jegyzeteléstechnika oktatását, mondván, hogy az túlzott egyénspecifikus volta miatt gyakorlatilag lehetetlen.

\subsubsection{Egyszerüsités}

Tapasztalatom szerint az egyik leghasznosabb jegyzetelési módszer az egyszerüsítés, hiszen elöfeltétele a megértés és az elemzés. Itt arról van szó, hogy egy több szóból álló kifejezés vagy mondatszegmens kifejezhető egy vagy két találó szóval, 
amely kvázi összefoglalja a jelentést. Ismert példa a jegyzetek világában pl. a $H I$ vagy a $T X$ rövidítés, amely hosszabb bevezetőt is takarhat (Sok szeretettel üdvözlöm tisztelt vendégeinket, illetve Engedjék meg, hogy kifejezzem hálámat..., stb.). Setton és Dawrant kötetében remek angol példákat olvashatunk, mint pl. achieve visibility with respect to $=$ see, vagy there's the possiblity that = might (2016a: 160); de ugyanezt a technikát gyakoroltatja egy korábbi feladatom is „Keep it short and simple" (KISS) címen (Szabó 2003: 114-115). ${ }^{4}$ Segítségünkre lehetnek a KISSalapelv megvalósításában az angol sajtónyelvben használt 4-5 betüs szavak (ZIPvocab), melyekre az alábbi alfejezetben (3.1.3) a rövidítések kapcsán példákat is adunk.

Külön feladatként érdemes gyakoroltatni az ún. ,gazdaságos parafrazálást”, tehát azt a technikát, hogy egyes hosszabb szavak, kifejezések helyettesítésére szinonimákat kérünk a jegyzetekben. Érdemes a feladatot közösen átbeszélni, a jó megoldásokat kiemelni. Ez az egyik leghasznosabb technika, és ha tudatosan odafigyelnek a hallgatók erre, előbb-utóbb kialakul az igényük a gazdaságos rövidítésre, tömörítésre. Láng Zsuzsa kiváló megfogalmazásában: azon kell igyekeznünk, hogy minél kevesebb jegyzettel minél több információt tudjunk előhívni a memóriánkból, és minél ügyesebben egészítsük azt ki a célnyelvi megfogalmazás során a jegyezetek alapján (2002: 129).

\subsubsection{Röviditések}

A tömörítés, illetve egyszerüsítés egyik válfaja a rövidítés, melynek hasznáról nemcsak tolmácsoknak szánt szakkönyvekben olvashatunk, de általánosabb jellegü (egyetemi hallgatóknak írt) müvekben is: egyértelmü, hogy ez a hatékonyság egyik eszköze. Rozan hét alapelve közül az egyik a rövidítés; szerinte a 4-5 betüs szavak jegyzetelése az ideális. Van, aki az első betű meghagyását javasolja, ami mindenképpen hasznos, hiszen a mentális lexikonban a kezdőbetű alapján tároljuk az anyanyelvi és idegen nyelvi szókincset is (Becker 1972: 30).

A rövidítések között több technika is említhető: íme egy lista a lehetőségekböl:

a) A már korábban is használt (pl. tanulmányok során kialakított) rövidítések alkalmazása, pl. konvencionális rövidítések: pl. $N B$ - nota bene, $B C$-i.e. - Krisztus elött stb. (Herbert 1952: 37; Matyssek 1989: 113);

b) Az első szótag megtartása $(G O V=$ government, $R E P=$ representative stb., bár itt óvatosnak kell lenni, hiszen egy szótag több célnyelvi változatot is elöhívhat, ami interferenciához vezethet (pl. exp - expert, expertise, export, expect stb. vagy magyarul gazd. - gazda, gazdag, gazdaság, gazdálkodás stb.);

c) A szótő megtartása és a végződés jelzése a felső indexben, pl. production - prod $^{n}$, government - gov $^{t}$, governance - gov $v^{c e}$ (Setton és Dawrant 2016a: 162); 
d) Ismert mozaikszavak használata (pl. $U N, E U, F B I$, CFSP, $M N B$ stb.), illetve a beszéd kulcskifejezésének (improvizatív) mozaikszavazása, pl. kergemarhakór $-K M K$ vagy private health insurance fund $-P H I F$ stb. Itt csak a kulcsszavakra érdemes ad-hoc szimbólumot alkotni, mert több improvizált rövidítést már nehezebb észben tartani;

e) Fontosabb betűk megtartása, kevésbé fontosak elhagyása, pl. arpln (airplane), cmtee (committee) vagy elfnt (elephant) (Nolan 2005: 296);

f) Mássalhangzók megtartása, magánhangzók elhagyása (mint Milne Micimackójában Bagoly), pl. prdctn, dvlpmnt, gvrmnt stb. - ugyanakkor kimutatták, hogy a nem anyanyelvü beszélök nehezen ismerik fel az idegen nyelvü szavakat, ha azokban nem szerepelnek magánhangzók (Setton és Dawrant 2016b: 184);

g) ZIP-vocab: a genfi iskolában használták, és a köznyelvben, illetve a (föként brit) sajtóban használt rövidítéseket tartalmazza: $A I D=$ assistance, support, $K E Y=$ significant, prominent stb. (Ilg és Lambert 1996:80, illetve Láng 2002: 132);

h) Latinból átvett rövid szavak: pl. ave, dux, dia, geo, rex, pax, vox (Ilg és Lambert 1996: 80) - bár manapság kevés tolmácsjelölt érkezik latinos háttérrel.

\subsubsection{Vizuális megjelenitések}

A vizuális megjelenítések között említhetjük a mind-mapping módszert (Windiari 2012), amelyet szintén nem csak tolmácsoknak javasolnak. A tolmácsoktatóknak létrehozott Orcit-honlapon (https://orcit.eu) több olyan feladat is szerepel, amely a beszéd vázát gondoltatja végig, vagy rajzoltatja le a hallgatókkal. Ezt a technikát kétféle módon is lehet gyakoroltatni: memóriából (tehát jegyzetelés nélkül utólag); a logikai elemzést elösegítendő, vagy jegyzetelés helyett - a beszéd vázát és főbb elemeit felmérendö.

A jegyzeteléstechnika egy másik különleges formája az ún. picture-based, vagyis rajzolós technika, ${ }^{5}$ ahol a tolmácsok gyakorlatilag lerajzolják a beszédet. Nyilván jól müködhet ez olyan szövegekkel, ahol a beszéd jellege ezt lehetővé teszi; de pl. egy gazdasági elemzés vagy egy jogi téma már kevésbé lehet alkalmas erre a módszerre. Érdemes lehet olyan beszédeket is keresni, amelyek a lineáris, balról jobbra haladó, és függőleges-lépcsőzetes elrendezéstől eltérő képi-vizuális megjelenitést tesznek lehetővé. Az ilyen példák megmutatása ösztönözheti a hallgatókat, hogy ha a beszéd (vagy annak egy-egy szakasza) erre alkalmas, bátran szakadjanak el a lineáris gondolkodásmódtól. 
1. ábra

Beszéd non-lineáris (vizuális) megjelenitése (Szabó 2003: 134)

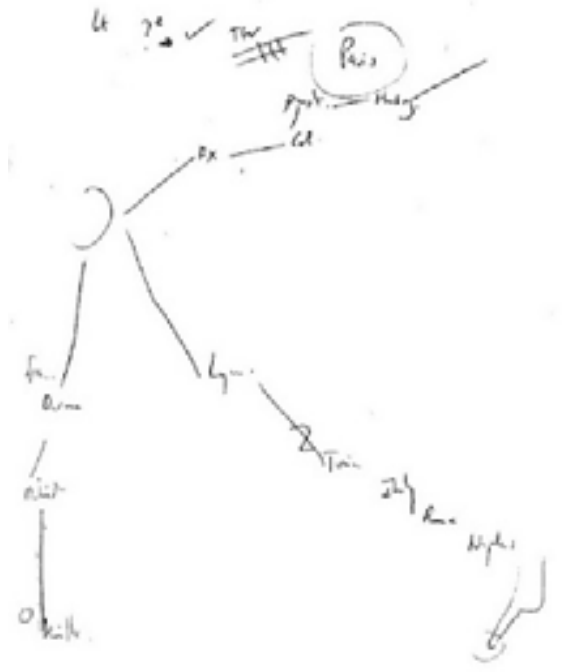

A jegyzetben ábrázolt szöveg:

In the long term the idea is to develop a European high-speed railway network with Paris at its centre. A line to the north will reach Brussels, where it can branch out to the east to Cologne, or continue further north to Amsterdam and later even Hamburg. To the south-east the line through Lyon will enter Italy through Turin and reach through Rome and Naples right down to the toe of Italy. And in the south-west a link up with Spain via Barcelona and then to Madrid will make it possible to extend the network down to Seville.

\subsubsection{Egyéb formai megfontolások}

A jegyzetek formájára vonatkozóan többféle tanácsot is kaphatunk különböző szerzők tollából. Rozan alapelvei között szerepel az az ajánlás, hogy igyekezzünk balról átlósan lefelé haladva, lépcsőzetes eltolással jegyzetelni. Ezt az elvet eddig még senki nem kérdőjelezte meg, noha Becker és Matyssek jegyzeteire szemmel láthatóan jellemzőbb a linearitás (lásd Láng 2002: 208-209). A legfontosabb szempont ezzel a technikával kapcsolatban is az, hogy a tolmács tudjon kiigazodni a saját jegyzetein, számára legyen értelmezhető a jegyzetek logikája és koherenciája.

\subsection{A jegyzetek formája: empirikus kutatások}

A rendelkezésre álló szakirodalom alapján elmondhatjuk, hogy a kutatókat elsősorban az foglalkoztatja, hogy a tolmácsok milyen arányban jegyeznek le egész szavakat, alkalmaznak rövidítéseket vagy szimbólumokat. Az 1. ábrán bemutatott 
vizuális megjelenítést csak limitáltan lehet a jegyzetekben alkalmazni, hiszen kevés szöveg alkalmas erre. Így az oktatásban csak érintőlegesen érdemes ezzel foglalkozni, ennélfogva a kutatások sem fókuszálnak ezekre a kreatív megoldásokra.

Silja Chen 2016-os cikkében összegyüjtötte a jegyzetek formájáról készült vagy azokat (is) vizsgáló tanulmányokat, és táblázatos formában azt kísérelte meg összefoglalni, hogy kutatások alapján (1) a nyelvi elemek vagy a szimbólumok jellemzőbbek-e a jegyzetekben; illetve (2) az egész szavak vagy a rövidítések vannak-e túlsúlyban (1 táblázat).

\section{1. táblázat}

Chen összehasonlitása (2016: 161)

\begin{tabular}{|l|l|l|l|l|l|l|}
\hline Tanulmány & Lung 2003 & $\begin{array}{l}\text { Dam } \\
\mathbf{2 0 0 4 a}\end{array}$ & $\begin{array}{l}\text { Dam } \\
\mathbf{2 0 0 4 b}\end{array}$ & $\begin{array}{l}\text { Dai és Xu } \\
\mathbf{2 0 0 7}\end{array}$ & Liu 2010 & $\begin{array}{l}\text { Wang et al } \\
\mathbf{2 0 1 0}\end{array}$ \\
\hline \multirow{2}{*}{ Eredmények } & $\begin{array}{l}\text { Nyelv> } \\
\text { szimbólum }\end{array}$ & $\begin{array}{l}\text { Nyelv> } \\
\text { szimbólum }\end{array}$ & $\begin{array}{l}\text { Nyelv> } \\
\text { szimbólum }\end{array}$ & $\begin{array}{l}\text { Nyelv> } \\
\text { szimbólum }\end{array}$ & $\begin{array}{l}\text { Nyelv> } \\
\text { szimbólum }\end{array}$ & $\begin{array}{l}\text { Nyelv> } \\
\text { szimbólum }\end{array}$ \\
\cline { 2 - 6 } & $\begin{array}{l}\text { Egész szó> } \\
\text { rövidítés }\end{array}$ & & $\begin{array}{l}\text { Egész szó> }> \\
\text { rövidítés }\end{array}$ & $\begin{array}{l}\text { Rövidítés }> \\
\text { egész szó }\end{array}$ & $\begin{array}{l}\text { Egész szó> }> \\
\text { rövidítés }\end{array}$ & $\begin{array}{l}\text { Rövidítés }> \\
\text { egész szó }\end{array}$ \\
\hline
\end{tabular}

Chen táblázatából világosan kiderül, hogy a nyelvi elemek (szavak) minden empirikus kutatás szerint hangsúlyosabban szerepelnek, mint a szimbólumok. ${ }^{6}$ A Matyssek-iskola követöinek kivételével tehát a szimbólumok - legalábbis a táblázat szerint - csak korlátozott számban szerepelnek a tolmácsok jegyzeteiben. Kiegészítésként érdemes megemlíteni jelen szerző doktori dolgozatát (Szabó 2005), amelyben nemcsak nyelvi, de formai szempontból is részletesen vizsgálja a kutatásba bevont tolmácsok jegyzeteit. ${ }^{7}$ Ezek az eredmények is azt mutatták, hogy a vizsgált alanyok elsősorban egész szavakat (45\%), másodsorban szimbólumokat (39\%) használtak; és meglepő módon a rövidítések száma a volt legalacsonyabb (16\%). Egybecsengtek ezek az adatok Dam pár évvel korábbi kutatásával is (2004a), ahol az alanyok viszonylag hasonló arányban használtak szimbólumokat (41\%) és egész szavakat (35\%), és valamivel kevesebb rövidítést (25\%). Természetesen ezen adatok alapján nem tudunk levonni messzemenő következtetéseket, hiszen a vizsgált alanyok száma még így is messze van attól az értéktől, amelyet reprezentatívnak nevezhetnénk. Lung 2003-as kutatása 17 alanyt vizsgált, Dam vizsgálatában mindössze 5 alany vett részt, és a magyar-angol nyelvpárt vizsgáló kutatásba (Szabó 2005, 2006) is csak 8 tolmácsot lehetett bevonni. ${ }^{8}$ A példák mindenesetre jól illusztrálják, milyen elenyésző az empirikus vizsgálódások száma, és a szórványosan megvalósuló kutatások milyen kicsi mintával tudnak számolni.

A tolmácsolás kutatásának ismert nehézségei ellenére akadnak még vállalkozó szellemü kutatók és érdekes kutatási témák. Cardoen 2013-as tanulmányában azt vizsgálta, hogy a jegyzetek milyen hatással vannak a tolmácsolás sebességére, 
azaz mi lehet az összefüggés a fluens vagy diszfluens előadásmód és a tolmácsjegyzetek között. A vizsgálat azt mutatta, hogy minél kevesebb volt a jegyzet, annál folyékonyabb volt a célnyelvi megfogalmazás, illetve a folyékonyabb tolmácsolás esetén több egész szó szerepelt a jegyzetben, mint rövidítés vagy szimbólum. Cardoen ezt azzal magyarázza, hogy az egész szavak kiolvasása kevesebb energiát vesz el, mint az egyes rövidítések kibogarászása (Cardoen 2013: 14), arról nem is beszélve, hogy az adott rövidítés megválasztása (lásd 3.1.3.) már a jegyzetelési szakaszban is elvonhatja a figyelmet.

\subsection{A jegyzetek formája: javaslatok oktatóknak}

A fentiek figyelembevételével mit javasolhatunk az oktatóknak? Elsősorban azt, hogy ismertessék meg a tolmácsjelöltekkel az összes lehetséges változatot (egész szavak, egyszerüsítés, rövidítések, szimbólumok, vizuális módszerek), és próbálják ki mindegyiket, minél változatosabb formában, minél több szöveggel. Érdemes sok feladatot adni autonóm tanulásra; lehet gyakorolni a jegyzetelést írott szövegekkel (pl. újságcikkek alapján) vagy a Speech Repository (illetve a SpeechPool) élőszóban előadott beszédeivel. A jegyzetekben alkalmazott redukciós vagy kreatív megoldások oktatásakor figyeljünk arra, hogy minél kevesebb legyen a redundancia, és minél nagyobb a koherencia. Mindig a szöveg makroszintjére fókuszáljunk, és ha a szöveg vázát, logikáját átlátják, akkor a mikroszintủ elemek többsége automatikusan a helyére kerül. Az angol KISS-szabály ${ }^{9}$ legyen a mérvadó: a kevesebb mindig több. Abban a legtöbb szerző egyetért, hogy a jegyzetben általában vegyesen szerepelnek szimbólumok, rövidítések és egész szavak; mint ahogy abban is, hogy a gyorsírás kerülendő (Dingfelder Stone 2014: 152) ${ }^{10}$. A hallgatók nézzenek meg videókat, figyeljék meg, ki hogyan jegyzetel; elemezzék egymás jegyzeteit, illetve a saját jegyzeteiket; és az ön- és társas értékelés eredményeit akár papírra is vethetik. Fejlődésük menetét (hibáikat, jó megoldásokat) rögzíthetik a tolmácsolási (gyakorlási) naplóban.

\section{Milyen nyelven jegyzeteljünk?}

E tanulmány harmadik témája az előző kettőhöz hasonlóan fontos és sokat vitatott kérdésként merül fel, amelynek komoly relevanciája van az oktatás szempontjából is.

\subsection{A jegyzetelés nyelve: preskriptív munkák}

A kezdeti időkben a gyakorló tolmácsok és/vagy oktatók a tolmácsolás iránya alapján (forrásnyelv, FNY vs. célnyelv, CNY) próbáltak javaslatot tenni. Több szerző is ('így pl. Herbert 1952; Rozan 1956, valamint Seleskovitch és Lederer 1995) a célnyelven történő jegyzetelést ajánlották, arra hivatkozva, hogy itt már menet 
közben megtörténik a kódváltás, és több energia marad a megfogalmazásra. Ugyanezt erösítette meg kísérleteivel Andres (2002), valamint saját szakmai tapasztalata alapján Jones (1998: 64) is.

A forrásnyelven történő jegyzetelés hívei (pl. Kirchhoff 1979; Ilg 1988; Alexieva 1994; Gile 1995/2009) azt állítják, hogy „,biztonságosabb” a bejövő nyelven jegyzeteket készíteni, éppen azért, mert itt egyfelöl több kapacitás kell a bejövő üzenet értelmezéséhez és elemzéséhez, másfelől a tolmács nem esik abba a csapdába, hogy idejekorán elkötelezi magát bizonyos célnyelvi megfelelők mellett. A gyakorlat, úgy tünik, inkább a $F N Y<C N Y$ mellett teszi le voksát: például a konferenciatolmácsok nemzetközi szövetsége, az AIIC is azt tanácsolja, hogy ,a jegyzetek nyelve legyen a célnyelv, ahol lehetséges, és a forrásnyelv, ahol szükséges (1994: 21)". A tolmácsolás oktatását lépésről lépésre vizsgáló, és a korábbi gyakorlati tapasztalatokat is számba vevő egyik legfrissebb kötet szerzői is a CNY$i$ jegyzetek mellett érvelnek, azt a szempontot is megemlítve, hogy a FNY-i jegyzetek visszaolvasásakor a produkciós fázisban fennállhat az interferencia veszélye (Setton és Dawrant 2016a). Létezik egy másik megfontolás is, amiért a célnyelven történő jegyzetelést ajánlják, nevezetesen az, hogy a figyelem és elemzés közben elvégzett jegyzetelés (párhuzamos szövegfeldolgozás) kiváló előkészítés a szinkrontolmácsoláshoz.

\subsection{A jegyzetelés nyelve: empirikus kutatások}

A 2000-es évek elején a korábbiaknál átfogóbb empirikus kutatást végzett Dam spanyol és dán nyelvpárral (2004a). Eredményei azt mutatták, hogy az alanyok többsége a célnyelven történő jegyzetelést részesítette előnyben. Egy másik vizsgálatban (2004b), amikor egy újabb változót is beiktatott a kísérletbe (a retourt, tehát anyanyelvről idegen nyelvre történő irányt), az adatok itt már arra utaltak, hogy az A nyelven, azaz anyanyelven történő jegyzetelés volt jellemző.

Jelen írás szerzője (Szabó 2006) magyar és angol viszonylatban vizsgálta ugyanezt a kérdést. A kutatás azonban nem erősítette meg sem a FNY/CNY alapján elváló preferenciát, sem pedig Dam vizsgálatának eredményét, amely az A irányba történő preferenciát mutatta ki. A magyar anyanyelvű konferenciatolmácsokkal végzett felméréséből ugyanis az derült ki, hogy a tolmácsok többségének jegyzeteiben a tolmácsolás irányától és személyes nyelvkombinációtól függetlenül az angol nyelv volt hangsúlyosabb - feltehetően annak köszönhetően, hogy az angol a magyarhoz képest sokkal gazdaságosabb nyelv; eleve rövidebbek a szavak, és a hosszabbakat is könnyebb rövidíteni. Ezeket a kísérleteket többen megismételték angol és kínai nyelvpárral (Dai és Xu 2007; Liu 2010; és Wang et al. 2010), de meglehetösen ellentmondó eredményeket kaptak. González (2012) három különböző szintű csoportot mért fel (kezdő, haladó, professzionális tolmácsok), és arra jutott, hogy minél nagyobb rutinnal rendelkezik az alany, annál jellemzőbben használja a célnyelvet a jegyzetekben - tehát több kapacitást tud felszabadítani az elemzési fázisban a kódváltásra (Gile 1995/2009). 
Baselli (2012) már vizsgálta egy harmadik (C) nyelv hatását is a jegyzetekre, de nem talált különösebb preferenciát egyik irányba sem, míg a Błaszczyk és Hanusiak 2010-ben végzett hasonló fókuszú, angol-lengyel nyelvpárt vizsgáló tanulmányából az derült ki, hogy a $\mathrm{C}$ nyelv egy-egy kulcsszó erejéig megjelenhet harmadikként a jegyzetben. Ugyanerről a jelenségröl számolt be jelen írás szerzőjének szóban és informálisan több tapasztalt tolmács is, akik német-magyar tolmácsolás esetén sokszor vetnek papírra angol szavakat, amely a korábban empirikus módon is bizonyított tételt támasztja alá, nevezetesen azt, hogy az angol (mint gazdaságos, és így jegyzetelésre kiválóan alkalmas nyelv) $\mathrm{C}$ nyelvi változatban is megjelenhet (Szabó 2006). A rövid angol szavak (but, so, if, tho, stb.) a nem angolos tolmácsok jegyzetében is megjelenhetnek, és kvázi szimbólumként funkcionálhatnak (Jones 1998: 53), bár pont a magyar nyelv ebből a szempontból hasonlóan helytakarékos (ld. de, igy, ha, stb.)

Silja Chen 2016-os tanulmányában összehasonlítja és táblázatba rendezi a jegyzetelés nyelvére vonatkozó empirikus kutatásokat (2. táblázat).

Mire következtethetünk a 2. táblázatból? Az bizonyosan látszik, hogy az alapvetően kismintás kísérletek, amelyek eltérő gyakorlattal rendelkező alanyokat, különböző nyelveket és nyelvi irányokat vizsgálnak, nem visznek minket közelebb a megoldáshoz. A nagy szórást mutató adatok mindenesetre megerősíteni látszanak azt a feltevést, hogy a nyelvválasztás erősen egyén-, illetve nyelvfüggő (illetve valószínüleg függ a feladat jellegétől/nehézségétől is). Az AIIC egy 1994-es továbbképzésén gyüjtött adatok is megerösítették azt a széles körben elterjedt feltételezést, miszerint a konferenciatolmácsok jegyzetei többnyire kevert nyelven készülnek, tehát, forrás- és célnyelvi (azaz A és B) elemet is tartalmaznak (angol esetén pedig nyilván angolt is, függetlenül a tolmácsolás irányától).

2. táblázat.

A jegyzetelés nyelvét vizsgáló empirikus kutatások egyes aspektusainak összehasonlitása (Chen 2016: 161)

\begin{tabular}{|c|c|c|c|c|c|c|c|c|c|}
\hline \multirow{2}{*}{$\begin{array}{l}\text { Tanul- } \\
\text { mány }\end{array}$} & \multicolumn{3}{|c|}{ Alanyok } & \multicolumn{5}{|c|}{ Szempontok } & Eredmények \\
\hline & \multicolumn{2}{|c|}{ szám } & $\begin{array}{l}\text { profi/ } \\
\text { hallg. }\end{array}$ & nyelvpár & irány & hossz & $\begin{array}{l}\text { idö- } \\
\text { tartam }\end{array}$ & sebesség & forma \\
\hline $\begin{array}{l}\text { Andres } \\
2002\end{array}$ & 28 & $\begin{array}{l}14 \\
14\end{array}$ & $\begin{array}{l}\text { profi } \\
\text { hallg. }\end{array}$ & $\begin{array}{l}\text { német } A \\
\text { francia } B\end{array}$ & B-A & NA & $6 " 27$ & $\begin{array}{l}167.9 \\
\text { szótag } \\
\text { /perc }\end{array}$ & $\begin{array}{l}\text { nyelv> } \\
\text { szimb. }\end{array}$ \\
\hline $\begin{array}{l}\text { Lung } \\
2003\end{array}$ & & 1 & hallg. & $\begin{array}{l}\text { kínai A } \\
\text { angol B }\end{array}$ & B-A & & NA & & $\begin{array}{l}\text { nyelv>szimb. } \\
\text { egész } \\
\text { szó>röv. }\end{array}$ \\
\hline
\end{tabular}




\begin{tabular}{|c|c|c|c|c|c|c|c|c|c|}
\hline \multirow{2}{*}{$\begin{array}{l}\text { Tanul- } \\
\text { mány }\end{array}$} & \multicolumn{3}{|c|}{ Alanyok } & \multicolumn{5}{|c|}{ Szempontok } & \multirow{2}{*}{$\begin{array}{c}\text { Eredmények } \\
\text { forma }\end{array}$} \\
\hline & szá & ám & $\begin{array}{l}\text { profi/ } \\
\text { hallg. }\end{array}$ & nyelvpár & irány & hossz & $\begin{array}{l}\text { idő- } \\
\text { tartam }\end{array}$ & sebesség & \\
\hline $\begin{array}{l}\text { Dam } \\
2004 a\end{array}$ & 4 & $\begin{array}{l}3 \\
1\end{array}$ & $\begin{array}{l}\text { hallg. } \\
\text { hallg. }\end{array}$ & \begin{tabular}{|l|} 
dán A, \\
spanyol B \\
spanyol A, \\
dán B \\
\end{tabular} & $\begin{array}{c}\text { mindkét } \\
\text { irány }\end{array}$ & & NA & & $\begin{array}{l}\text { nyelv>szimb. } \\
\text { egész } \\
\text { szó>röv. }\end{array}$ \\
\hline $\begin{array}{l}\text { Dam } \\
2004 b\end{array}$ & 5 & & profi & $\begin{array}{l}\text { dán A } \\
\text { spanyol B }\end{array}$ & A-B & $\begin{array}{l}1081 \\
\text { szó }\end{array}$ & $7 " 30$ & NA & $\begin{array}{l}\text { nyelv>szimb. } \\
\text { egész } \\
\text { szó>röv. }\end{array}$ \\
\hline $\begin{array}{l}\text { Lim } \\
2006\end{array}$ & 4 & & hallg. & $\begin{array}{l}\text { koreai A } \\
\text { angol B }\end{array}$ & A-B & & NA & & NA \\
\hline $\begin{array}{l}\text { Szabó } \\
2006\end{array}$ & 8 & 8 & profi & $\begin{array}{l}\text { magyar A } \\
\text { angol B }\end{array}$ & $\begin{array}{c}\text { mindkét } \\
\text { irány }\end{array}$ & & NA & & NA \\
\hline \begin{tabular}{|l} 
Dai és \\
Xu \\
2007
\end{tabular} & 1 & & hallg. & $\begin{array}{l}\text { kínai A } \\
\text { angol B }\end{array}$ & A-B & $\begin{array}{c}529 \\
\text { leütés }\end{array}$ & NA & NA & $\begin{array}{l}\text { röv. > egész } \\
\text { szó }\end{array}$ \\
\hline $\begin{array}{l}\text { Liu } \\
2010\end{array}$ & 12 & 20 & hallg. & $\begin{array}{l}\text { kínai A } \\
\text { angol B }\end{array}$ & A-B & $\begin{array}{c}518 \\
\text { leütés }\end{array}$ & & $\begin{array}{l}200 \text { le- } \\
\text { ütés/perc }\end{array}$ & $\begin{array}{l}\text { nyelv>szimb. } \\
\text { egész } \\
\text { szó>röv. }\end{array}$ \\
\hline $\begin{array}{l}\text { Wang } \\
\text { et al. } \\
2010\end{array}$ & 1 & 2 & hallg. & $\begin{array}{l}\text { kínai A } \\
\text { angol B }\end{array}$ & $\begin{array}{c}\text { mindkét } \\
\text { irány }\end{array}$ & \begin{tabular}{|c|}
135 \\
szó \\
163 \\
leütés
\end{tabular} & & & $\begin{array}{l}\text { nyelv>szimb. } \\
\text { egész } \\
\text { szó>röv }\end{array}$ \\
\hline $\begin{array}{l}\text { Gon- } \\
\text { zalez } \\
2012\end{array}$ & 30 & $\begin{array}{l}10 \\
20\end{array}$ & $\begin{array}{l}\text { profi } \\
\text { hallg. }\end{array}$ & $\begin{array}{l}\text { spanyol A } \\
\text { angol B }\end{array}$ & $B-A$ & $\begin{array}{l}711 \\
\text { Szó }\end{array}$ & & $\begin{array}{l}125 \text { szó/ } \\
\text { perc }\end{array}$ & NA \\
\hline
\end{tabular}

\subsection{A jegyzetek nyelve: javaslatok az oktatóknak}

Milyen tanulságokat vonhatunk le az oktatás szempontjából? A jegyzeteléstechnika oktatásában a nyelvi irány kérdésében arra kell figyelnünk, hogy a hallgatókat megismertessük a választási lehetőségekkel (forrásnyelv vs. célnyelv; A nyelv vs. $\mathrm{B}$ nyelv, esetleg $\mathrm{C}$ nyelv, illetve nyelvtől és iránytól függetlenül az angol [?]), és a hallgatók kísérletezzenek kedvükre, azaz tapasztalják meg, hogy számukra melyik az ideális megoldás, illetve mely elemek kombinációja lehet nekik a leginkább 
testhezálló. Érdemes kipróbálni a hallgatókkal mindegyik verziót először az egyes technikák kombinációja nélkül. Adjunk nekik különbözö jellegü szövegeket, és jegyzeteljenek csak FNY-en, csak CNY-en, az iránytól függetlenül A vagy B nyelvükön; majd ezt követően kezdjék el tesztelgetni, hogy mi esik nekik jobban „kézre". Figyeljünk arra is, hogy a jegyzetek nyelve sosem egyfajta elszigetelt kérdés: egyrészt függ az adott nyelvtől, másrészt minden esetben együtt jár a jegyzetek formájára (szavak, rövidítések, szimbólumok stb.) vonatkozó megfontolásokkal. A szerző angol-magyar nyelvpárban szerzett oktatási tapasztalata pedig azt mutatja, hogy érdemes az angol nyelv adta gazdaságosságára alapozni; különösen a rövid angol szavakkal kifejezett egyszerüsítés (zipping) mutat jó eredményeket.

\section{5. Összefoglalás}

A jegyzeteléstechnika az egyik olyan terület a konszekutív tolmácsolás oktatásában, ahol jelenleg is minimális konszenzus van arra vonatkozóan, hogy mit kellene vagy lenne érdemes tanítani. Abban többnyire megegyeznek a vélemények, hogy nincs egyfajta univerzális, mindenki számára müködő recept, így azt javasolják, hogy bizonyos alapvetések figyelembevételével és rengeteg gyakorlattal minden tolmács egyénileg fejlessze ki a maga jegyzetelési technikáját.

A tanulmány a konszekutív, hosszúszakaszos tolmácsolás során alkalmazott jegyzeteléstechnika oktatásában felmerülő három legnagyobb dilemmát járta körül: Mit/Mennyit irjunk le? Hogyan jegyzeteljünk? Milyen nyelven? Mindhárom terület kapcsán megvizsgáltuk a szakirodalom elöíró jellegủ tanácsait, illetve releváns módszertani javaslatait e dilemmák kezelésére. Számba vettük a fenti kérdésekkel foglalkozó fontosabb empirikus kutatásokat is, majd ezt követően levontunk néhány lehetséges módszertani tanulságot a szerző személyes oktatói tapasztalata alapján.

A tanulmány elsőként a jegyzetek tartalmát, azaz a Mit és mennyit? kérdését vizsgálta meg. Itt felhívtuk a figyelmet, hogy a jegyzeteket csak egy későbbi fázisban vezessük be, mindig a szöveg makrostruktúrája legyen az elsődleges szempont, és a jegyzetek mennyisége soha ne menjen a megértés és elemzés rovására. A javaslatok között említettük még a beszédek nehézségének megválasztását (graduálás), illetve a párhuzamosan alkalmazott kulcsszavazós (a memóriát jobban igénybe vevő) technika jelentőségét. Másodsorban megvizsgáltuk a jegyzetek formai megjelenítésének lehetőségeit; itt a Hogyan? kérdésre kerestünk válaszokat. Összefoglaló jelleggel beszámoltunk az opciókról: egész szavak leírása, egyszerüsítés, rövidítési technikák, szimbólumok, illeti egyéb, képi-vizuális megjelenítést lehetővé tevő technikák. Az egyszerűsítés kapcsán hangsúlyoztuk a „gazdaságos parafrazálás" módszerét, amely segíthet az elemzés elvégzésében is, és felhívtuk a figyelmet a koherencia szükségességére valamint a redundanciák kiküszöbölésére. Ebben a tekintetben is fontosnak érezzük az autonóm tanulásban rejlö lehe- 
tőségeket, illetve a társas és egyéni értékelési módokat, valamint a tolmácsolási napló (logbook) használatát, amelyben a hallgatók nyomon tudják követni saját fejlödésüket.

A tanulmányban vizsgált harmadik terület a jegyzetek nyelvét helyezte a középpontba. Láthattuk, hogy sem a preskriptív, tapasztalati alapon adott ajánlások, sem a (kismintás) empirikus kutatások nem vittek minket közelebb annak megválaszolásához, hogy milyen nyelven érdemes jegyzetelni. Az oktatók számára megfogalmazott javaslatok között szerepel az, hogy meg kell ismertetni a hallgatókat a lehetőségekkel (forrásnyelv vs. célnyelv, A nyelv vs. B nyelv, illetve amit lehet, angolul), és egyénileg döntsék el, hogy kinek-kinek mi a legtesthezállóbb. A szerző tapasztalata szerint az angol nyelvü egyszerüsítések és rövidítések (ZIP-vocab) nagyon hasznosak, és a vegyes nyelvü jegyzetelés bizonyosan nem gátolja a tolmácsokat a megértésben és az elemzésben.

Ha a fentiekben vázolt törekvéseket (ajánlásokat, kutatásokat stb.) áttanulmányozzuk, annyit biztosan kijelenthetünk, hogy a jegyzeteléstechnikát lehet, és legföképpen érdemes tanítani.

\section{Jegyzetek}

${ }^{1}$ A konferenciatolmácsok nemzetközi szövetségének, az AIIC-nak holnapjáról: https:// aiic.net/node/7/how-interpreters-work/lang/1.

${ }^{2}$ Chen 2016-os tanulmánya egy egész fejezetet szentel a jegyzetelés és a tolmácsolás minősége közötti összefüggésnek (2016:162).

${ }^{3}$ A fejlesztő értékelés különböző formáit (pl. társas értékelés vagy önértékelés) érdemes használni a jegyzetek értékelésében, ennek jó példája lehet a gyakorlási napló. Az autonóm tanulás különböző formáiról és a gyakorlási napló felhasználásáról bővebben Pataky és Móricz (2017) írásában olvashatunk. A fejlesztő értékelésről bővebben ld. a szerző tanulmányát Szabó (előkészületben).

${ }^{4}$ A Recipe Book néven ismert kötet 2003-ban készült a British Council támogatásával. Az angol nyelvü könyv összeállításában több hazai szakember is részt vett, név szerint Durham Mária, Gulyás Róbert, Majzik György, Mester Ildikó, Sándor Klaudia, Varga Vanda és Volford Katalin, akik később szinte kivétel nélkül mind az Európai Parlament fóállású vagy szabadúszó tolmácsaként dolgoztak, vagy dolgoznak ma is. A kötet első felében tanulmányokat olvashatunk, (pl. meghívott szakértőként Franz Pöchhacker foglalja össze a tolmácsoláskutatás akkori főbb irányait), a második rész pedig osztálytermi kipróbálásra és autonóm tanulásra szánt ötleteket, feladatokat tartalmaz.

${ }^{5}$ Egy ilyen tolmácsolást láthatunk videón itt: https://www.glendon.yorku.ca/interpretation/2015/01/11/are-you-looking-for-a-fresh-take-on-consecutive/

${ }^{6}$ A táblázatban feltüntetett utolsó három tanulmány kínai nyelven érhető el.

${ }^{7}$ A doktori dolgozat egyik fejezetének kutatási eredményei olvashatók az Interpreting folyóirat 2006. Vol. 8. No. 2. számában.

${ }^{8}$ Még a táblázatban feltüntetett kínai kutatásokban is csak 12-12 alany szerepelt.

${ }^{9}$ Keep It Short and Simple $=$ röviden és egyszerüen 
${ }^{10}$ A gyorsírás ugyanis a hangalakra (vagyis a formára) utal vissza, míg tolmácsolás közben elsődleges célunk a deverbalizáció (Seleskovitch és Lederer 1989), így nem hasznos, ha formára emlékeztető módszert választunk.

\section{Irodalom}

Ahrens, B. 2005. Rozan and Matyssek: Are they really that different? A comparative synopsis of two classic note-taking schools. Forum Vol. 3. No. 2. 1-15. DOI: https:// doi.org/10.1075/forum.3.2.01ahr

AIIC. 1994. Interpreter Training Workshop, Poznan, 1994. április 8-10. Genf, AIIC.

Alexieva, B. 1994. On teaching note-taking in consecutive interpreting. Teaching translation and interpreting Vol. 2. 199-206. DOI: https://doi.org/10.1075/btl.5.28ale

Allioni, S. 1989. Towards a grammar of consecutive interpretation. In: The theoretical and practical aspects of teaching conference interpretation. 191-197.

Andres, D. 2002. Konsekutivdolmetschen und Notation. Frankfurt: P. Lang.

Baselli, V. 2012. Which language do interpreters use in Consecutive Interpreting? Advanced Research in Scientific Areas. December, 3-7 2012. Available at: http://www. arsa-conf.com

Becker, W. 1972. Notizentechnik. Germersheim: BBK Gesellschaft für moderne Sprachen $\mathrm{mbH}$.

Besznyák, R. (elökészületben): Tolmácsolási gyakorlószövegek graduálása lexikai csapdák elemzésével. In: Szabó, Cs., Bakti, M. (szerk.) Iránytü a tolmácsolás oktatásához. A kompetenciafejlesztés új fókuszai. Szeged: Juhász Gyula Felsőoktatási Kiadó.

Błaszczyk P., Hanusiak D. 2010. The Choice of Language for Note-taking for Consecutive Interpreting: A Polish Perspective. In: MikaEL Kääntämisen ja tulkkauksen tutkimuksen symposiumin verkkojulkaisu. Electronic proceedings of the KäTu symposium on translation and interpreting studies Vol. 4.

Cardoen, H. (ed.) 2013. The Effect of Note-taking on Target-Text Fluency. Leuven: CETRA. Chen, S. 2016. Note-taking in consecutive interpreting: A review with special focus on Chinese and English literature. The Journal of Specialised Translation Vol. 26. No. 1. 151-171.

Chen, S. 2017a. Note-taking in consecutive interpreting: New data from pen recording. Translation \& Interpreting Vol. 9. No. 1. 4-23. DOI: https://doi.org/10.12807/ ti.109201.2017.a02

Chen, S. 2017b. The construct of cognitive load in interpreting and its measurement. Perspectives Vol. 25. No. 4. 640-657. DOI: https://doi.org/10.1080/090767 6X.2016.1278026

Chuang, Li-ling 2008. Note-Taking Know-How: A Processing Perspective on Consecutive Interpreting. Spectrum: Studies in Language, Literature, Translation, and Interpretation, Vol. 2. 93-101.

Dai, W., Xu, H. 2007. An empirical study of the features of interpreters' notes in ChineseEnglish consecutive interpreting: The examples of professionally trained and unprofessional interpreters. Foreign Language Teaching and Research Vol. 39. No. 2. 136-144. (kínaiul) 
Dam, H. V. 2004a. Interpreters' notes: On the choice of form and language. In: G. Hansen, K. Malmkjær, D. Gile (eds) Claims, changes and challenges in Translation Studies. Amsterdam/Philadelphia: John Benjamins. 251-261. DOI: https://doi.org/10.1075/ btl.50.21dam

Dam, H. V. 2004b. Interpreters' notes. Interpreting Vol. 6. No. 1. 3-17. DOI: https://doi. org/10.1075/intp.6.1.03dam

Deng, Y. 1991. Consecutive notes: An artist's tool. In: Liu, C. (ed.) Collected Essays on Translation. Hong Kong: Commercial Press. 284-292.

Dingfelder Stone, M. 2014. The theory and practice of teaching note-taking. In: To Know How to Suggest...: Approaches to Teaching Conference Interpreting. Vol. 16. Berlin: Frank \& Timme.145-166.

Gile, D. 1995/2009. Basic concepts and models for interpreter and translator training. Amsterdam/Philadelphia: John Benjamins. DOI: https://doi.org/10.1075/btl.8(1st)

Gillies, A. 2004. Conference interpreting: a new students' companion (Vol. 7). Krakow: Tertium.

Gillies, A. 2017. Note-taking for consecutive interpreting: A short course (2nd ed.). London: Routledge. DOI: https://doi.org/10.4324/9781315648996

González, M. A. 2012. The language of consecutive interpreters' notes: differences across levels of expertise. Interpreting Vol.14. No. 1. 55-72. DOI: https:/doi.org/10.1075/ intp.14.1.03abu

González, R. D., Vásquez, V. F., Mikkelson, H. 1991. Fundamentals of court interpretation. Durham, NC: Carolina Academic Press. 243-244.

Herbert, J. 1952. The interpreter's handbook: How to become a conference interpreter. Genève: Librairie de l'Universit.

Ilg, G. 1988. La prise de notes en interprétation consécutive. Une orientation générale. Parallèles Vol. 9. 9-13. DOI: https://doi.org/10.1075/babel.3.1.05pri

Ilg, G., Lambert, S. 1996. Teaching consecutive interpreting. Interpreting Vol. 1. No. 1. 69-99. DOI: https://doi.org/10.1075/intp.1.1.05ilg

Jones, R. 1998/2014. Conference interpreting explained. Manchester: St Jerome Publishing. DOI: https://doi.org/10.1075/intp.3.2.05mac_

Kirchhoff, H. 1979. Die Notationssprache als Hilfsmittel des Konferenzdolmetschers im Konsekutivvorgang. In: Sprachtheorie und Sprachpraxis. 121-133.

Láng, Zs. G. 2002. Tolmácsolás felsöfokon: A hivatásos tolmácsok képzéséröl. Budapest: Scholastica.

Lim, Hyang-Ok 2006. A post-mortem of note-taking. Forum Vol. 4. No. 2. 89-112. DOI: https://doi.org/10.1075/forum.4.2.06lim

Liu, J. 2010. Note-taking characteristics of English majored undergraduates in ChineseEnglish consecutive interpreting: an empirical study based on students' consecutive interpreting notes. Foreign Language World (kínaiul).

Lung, R. 2003. Taking "notes" seriously in the interpretation classroom. In: Aís, Á. C. Sánchez, M. M. F., Gile, D. (eds) La evaluación de la calidad en interpretación: investigación. Granada: Comares. 199-205.

Matyssek, H. 1989. Handbuch der Notizentechnik für Dolmetscher. Heidelberg: Groos.

Mead, P. 2011. Co-ordinating delivery in consecutive interpreting. inTRAlinea. Online Translation Journal. Vol. 13.

Nolan, J. 2005. Interpretation: Techniques and exercises. Bristol: Multilingual Matters. 
Pataky, É., Móricz, K. A. 2017. Irányított tolmácsolási gyakorlat - tanulói autonómia a tolmácsolás oktatásában. Modern Nyelvoktatás 23. évf. 2-3. szám. 7-20.

Rozan, J. F., Hrehorowicz, U. 1956/2004. Note-taking in consecutive interpreting. Cracow: Cracow Tertium Society for the Promotion of Language Studies.

Sawyer, D. B. 2004. Fundamental aspects of interpreter education: Curriculum and assessment (Vol. 47). Amsterdam/Philadelphia: John Benjamins Publishing. DOI: https://doi.org/10.1075/btl.47

Seleskovitch, D. 1975/2002. Language and memory: A study of note-taking in consecutive interpreting. In: The Interpreting Studies Reader. London and New York: Routledge. $121-129$.

Seleskovitch, D. 1999. The teaching of conference interpretation in the course of the last 50 years. Interpreting. Vol. 4. No. 1. 55-66. DOI: https://doi.org/10.1075/intp.4.1.07sel

Seleskovitch, D., Lederer, M. 1989. A Systematic Approach to Teaching Interpretation. Luxembourg: Pedagogie Raisonnee de l'interpretation.

Seleskovitch, D., Lederer, M. 1995. A Systematic Approach to Teaching Interpretation. Registry of Interpreters for the Deaf.

Setton, R., Dawrant, A. 2016a. Conference interpreting: A complete course (Vol. 120). Amsterdam/Philadelphia: John Benjamins Publishing Company. DOI: https://doi. org $/ 10.1075 /$ btl.120

Setton, R., Dawrant, A. 2016b. Conference interpreting: A trainer's guide (Vol. 121). Amsterdam/Philadelphia: John Benjamins Publishing Company. DOI: https://oi. org $/ 10.1075 /$ btl.121

Szabó, Cs. (szerk.) 2003. From preparation to performance: Recipes for practitioners and teachers. Budapest: British Council.

Szabó, Cs. 2005. Note-taking Techniques and Strategies in Consecutive Interpreting: An Empirical Investigation of the Choice of Language, Choice of Form and Means of Compression. Pécs. Kiadatlan doktori disszertáció.

Szabó, Cs. 2006. Language choice in note-taking for consecutive interpreting. Interpreting Vol. 8. No. 2. 129-147. DOI: https://doi.org/10.1075/intp.8.2.02sza

Szabó Cs. (előkészületben). Fejlesztő értékelési technikák a tolmácsolás oktatásában. In: Szabó Cs., Bakti M. (szerk.) Iránytü a tolmácsolás oktatásához. A kompetenciafejlesztés új fókuszai. Szeged: Juhász Gyula Felsőoktatási Kiadó.

Thiéry, C. 1981. L'enseignement de la prise de notes en interprétation consécutive: un faux problème? In : L'Enseignement de la Traduction et de l'Interprétation. De la Théorie à la Pédagogie. Ottawa: Éditions de l'Université d'Ottawa. 99-112.

Wang, W., Dandan, Z., Ling, W. 2010. An empirical study of note-taking characteristics and output quality in interpreting. Foreign Language World. Vol. 4. 9-18. (kinaiul)

Windiari, N. L. 2012. Note Taking and the Power of Mapping in Consecutive Interpreting. Udayana University.

https://www.academia.edu/1478502/note_taking_and_the_power_of_mind_mapping _ in consecutive interpreting

Yamada, H. 2018. Validity of Note-taking for New Consecutive Interpreting Learners: An Empirical Study of University Interpretation Courses. Theory and Practice in Language Studies Vol. 8. No. 11. 1387-1396. DOI: https://doi.org/10.17507/tpls.0811.02 